LUBLIN STUDIES IN MODERN LANGUAGES AND

LITERATURE 41(1), 2017, HTTP://WWW.LSMLL.UMCS.LUBLIN.PL, HTTP://LSMLL.JOURNALS.UMCS.PL

\author{
Astrid Ebenberger \\ University College of Teacher Education \\ of Christian Churches, Wien/Krems \\ Dr. Gschmeidler Straße 22-30 \\ 3500 Krems, Austria
}

\title{
Developing Individual Language Competences via Task-Based-Learning (TBL) and Content and Language Integrated Learning (CLIL)
}

\begin{abstract}
School classes are not any longer considered to be homogeneous systems. Diversity in different aspects has become obvious and appreciated as a benefit. In order to profit from this benefit in the case of the individual development of pupils didactical approaches have to focus on differentiation and individualization. English language teaching is very often based on wide-spread, common schoolbooks which integrate different methods. Dealing with the diversity of a class means to select work and exercises carefully according to the needs of the children. In order to this fact the article presents selected lesson plans designed by students at KPH Wien/Krems as learning outcomes in a workshop especially focused on differentiation and individualization in ELT. "Content and Language Integrated Learning" (CLIL) and "Task-Based Learning" (TBL) were described and considered as appropriate didactical approaches to deal with this diversity. Therefore the selected examples include the most important aspects of each way based on the paradigms of differentiation and individualization. As a feedback to the lesson plans teacher-trainers pointed out advantages concerning the motivation and self-conducted
\end{abstract}


work of the children but complained about the time-consuming preparation work and a lack of knowledge of the teachers about TBL and CLIL

Keywords: CLIL; TBL; ELT; differentiation; individualization; competences

\section{Introduction}

In Austria optional English language teaching (ELT) starts in kindergarten. It becomes obligatory and curriculum-based in the first year of primary school. Schools are allowed to decide autonomously if they offer - depending on their financial and human resources additional courses for gifted and interested young learners. Therefore the outcomes and competences of learners after four years of obligatory ELT sometimes differ tremendously when children proceed to secondary education. Dealing with a heterogeneous group of language learners and catering for individual needs, competences and prior knowledge seems to be one of the most important and most difficult challenges each teacher, even at primary school level, has to focus on. The aspects of differentiation and individualization have become crucial for the success of a teaching and learning process. Concepts like task-based learning (TBL) and content and language integrated learning (CLIL) support the increase of proficiency, accuracy and fluency in English as a foreign language. The methods require the preparation of different material and different exercises due to different prior knowledge, different depth of knowledge and different interests of learners. Based on these aspects the paper presents examples and lesson plans that support the development of individual language competences.

\section{Main aspects}

In Austria ELT is based on a national core curriculum as in most European countries. During the last years another framework has been created. Basic Competences Foreign Language Alive (GK2, GK4) combine and integrate the national curriculum and language competences defined via the Common European Framework of 
References for Languages, GERS (Council of Europe 2001) as a guideline to reaching the level of A1. This book of competences provides standards for ELT to support the methodological choice of teachers and offers an orientation for language teachers of secondary schools. Above all, it requires transparency for both learners and parents (ÖSZ 2015).

\subsection{Curriculum and basic language competences (GK 2, GK 4)}

The national core curriculum states foreign language teaching as an obligatory subject starting form the first year of mandatory school. It is called an "obligatory exercise" in primary school (Bgbl. II Nr. 303/ 2012) meaning that pupils do not receive any grades. In secondary school (Bgbl. II Nr. 185/2012) it becomes an obligatory subject with oral and written formal and informal tests, standardized testing (Bgbl. II Nr. 1/2009) in year 4 of secondary school and grading after each term. The table of contents in primary school focuses on the child and its environment (personal situation, friends, family, nature, daily routine ...) and expands in secondary school towards the world and current political, personal, technical and environmental issues. In both stages intercultural aspects and dealing with information and communication technologies have become essential. The curriculum defines what the children should know, whereas the book of competences defines what the children should be able to do. This framework proposes and describes basic competences in the different skills like listening, speaking, reading and writing after two years (GK2) and four years (GK4) of ELT (ÖSZ 2015). In contrast to the national curriculum it suggests the development of writing skills from the time children are able to read. 
Developing Individual Language Competences via TBL and CLIL 177

Table 1. Speaking competences in primary schools (GK2/GK4) (English version after ÖSZ, 2015)

\begin{tabular}{|c|c|c|c|c|}
\hline \multicolumn{5}{|c|}{ GK $2 \rightarrow$ increasing complexity $\rightarrow$ GK 4} \\
\hline & \multicolumn{2}{|c|}{ 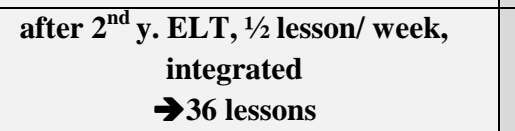 } & \multicolumn{2}{|c|}{$\begin{array}{c}\text { After } 4^{\text {th }} \mathbf{y} \text {. ELT, } 1 \text { single lesson/ } \\
\text { week } \\
\Rightarrow \text { min. } 72 \text { lessons }\end{array}$} \\
\hline \multicolumn{5}{|c|}{$\Rightarrow$ around 108 lessons in primary school } \\
\hline \multicolumn{5}{|c|}{ SPEAKING COHERENTLY } \\
\hline 1 & \multicolumn{4}{|c|}{$\begin{array}{l}\text { Giving information to already taught issues with the help of very simple } \\
\text { communication means and the use of multi-sensory support }\end{array}$} \\
\hline & $\begin{array}{l}1 \\
\mathbf{a}\end{array}$ & $\begin{array}{l}\text { Simply talking about oneself: } \\
\text { appearance, likes/dislikes, feelings, } \\
\text { wishes }\end{array}$ & $\begin{array}{l}1 \\
\mathbf{a}\end{array}$ & $\begin{array}{l}\text { Talking about and describing } \\
\text { oneself }\end{array}$ \\
\hline & $\begin{array}{l}\mathbf{1} \\
\mathbf{b}\end{array}$ & $\begin{array}{l}\text { Making simple statements on the } \\
\text { personal environment }\end{array}$ & $\begin{array}{ll}\mathbf{1} \\
\mathbf{b}\end{array}$ & $\begin{array}{l}\text { Making simple statements on } \\
\text { family, peers, school, daily } \\
\text { routine, cycle of the year, } \\
\text { weather, clothes, health and } \\
\text { nutrition, leisure time } \\
\text { activities; about personal } \\
\text { environment, nature and } \\
\text { different subject-based (arts, } \\
\text { biology, mathematics, music, } \\
\text { science, crafts) issues }\end{array}$ \\
\hline & $\begin{array}{l}1 \\
\mathbf{c}\end{array}$ & $\begin{array}{l}\text { Making simple subject-based } \\
\text { statements (arts, biology, } \\
\text { mathematics, music, science, } \\
\text { crafts) }\end{array}$ & $\begin{array}{l}\mathbf{1} \\
\mathbf{c}\end{array}$ & $\begin{array}{l}\text { Ability to express feelings, } \\
\text { likes and dislikes, wishes }\end{array}$ \\
\hline 2 & \multicolumn{4}{|c|}{$\begin{array}{c}\text { Reproducing already known short and simple texts using multi-sensory } \\
\text { support }\end{array}$} \\
\hline & $\begin{array}{l}2 \\
\mathbf{a}\end{array}$ & $\begin{array}{l}\text { Reproducing very simple rhymes, } \\
\text { chants and lyrics }\end{array}$ & $\begin{array}{l}2 \\
\mathbf{a}\end{array}$ & $\begin{array}{l}\text { Reproducing rhymes, chants } \\
\text { and lyrics }\end{array}$ \\
\hline & $\begin{array}{ll} \\
\mathbf{b}\end{array}$ & $\begin{array}{l}\text { Reproducing very simple parts of } \\
\text { texts like stories (alone or in } \\
\text { groups) }\end{array}$ & $\begin{array}{l}\mathbf{2} \\
\mathbf{b}\end{array}$ & $\begin{array}{l}\text { Reproducing very simple and } \\
\text { short (pictures or films) stories }\end{array}$ \\
\hline \multicolumn{5}{|c|}{ JOIN IN COMMUNICATION } \\
\hline 1 & & $\begin{array}{r}\text { Getting in contact with children an } \\
\text { communica }\end{array}$ & & $\begin{array}{l}\text { ults based on already taught } \\
\text { ssues }\end{array}$ \\
\hline
\end{tabular}




\begin{tabular}{|c|c|c|c|c|}
\hline & $\begin{array}{l}1 \\
\mathrm{a}\end{array}$ & $\begin{array}{l}\text { Greeting and saying good-bye in } \\
\text { different situations }\end{array}$ & $\begin{array}{l}1 \\
\mathrm{a}\end{array}$ & $\begin{array}{l}\text { Greeting and saying good-bye } \\
\text { in different situations }\end{array}$ \\
\hline & $\begin{array}{l}1 \\
b\end{array}$ & $\begin{array}{l}\text { Simply asking and answering } \\
\text { during the lesson }\end{array}$ & $\begin{array}{l}1 \\
b\end{array}$ & $\begin{array}{l}\text { Simply asking and answering } \\
\text { during the lesson }\end{array}$ \\
\hline 2 & \multicolumn{4}{|c|}{ Short and simple communication supported by phrases, pictures } \\
\hline & $\begin{array}{l}2 \\
\mathbf{a}\end{array}$ & $\begin{array}{l}\text { Joining in very simple } \\
\text { communicative situations about } \\
\text { daily routine, e.g. shopping } \\
\text { dialogues, asking, expressing } \\
\text { wishes via role-plays, }\end{array}$ & $\begin{array}{l}\mathbf{2} \\
\mathbf{a}\end{array}$ & $\begin{array}{l}\text { Joining in very simple } \\
\text { communicative situations } \\
\text { about family, peers, school, } \\
\text { daily routine, cycle of the year, } \\
\text { weather, clothes, health and } \\
\text { nutrition, leisure time } \\
\text { activities; about personal } \\
\text { environment, nature and } \\
\text { different subject-based issues } \\
\text { (arts, biology, mathematics, } \\
\text { music, science, crafts) }\end{array}$ \\
\hline & $\begin{array}{l}2 \\
\mathbf{b}\end{array}$ & $\begin{array}{l}\text { Joining in very simple } \\
\text { communication on different } \\
\text { subject-based issues (arts, biology, } \\
\text { mathematics, music, science, } \\
\text { crafts) }\end{array}$ & $\begin{array}{l}2 \\
\text { b }\end{array}$ & $\begin{array}{l}\text { Managing very simple } \\
\text { communicative situations e.g. } \\
\text { shopping, asking, responding, } \\
\text { expressing wishes, offering } \\
\text { and reacting }\end{array}$ \\
\hline & & & $\begin{array}{l}2 \\
\text { c }\end{array}$ & $\begin{array}{l}\text { Reproducing very simple } \\
\text { dialogues and stories }\end{array}$ \\
\hline
\end{tabular}

\subsection{Differentiation and individualization}

Classes are recognized as heterogeneous systems of individual pupils, different in their social, cultural and linguistic background, diverse in their interests, gifts, skills, motivation and experience, and different in their characters, sometimes also in their age (Altrichter and Hauser 2007: 6). In former days the homogenous class was considered as the ideal one. It has become obvious that this situation has never existed and dealing with diversity includes great opportunities for the development of each single child. Class-internal differentiation via different social forms (groupings, pair work, etc) and different tasks has become crucial. Differentiation can be considered to be the methodological approach of teachers to deal with the diversity in class and to provide individual access for each child (Salner-Gridling 2009). Therefore material and tasks have to follow certain principles: they 
Developing Individual Language Competences via TBL and CLIL 179

should address multiple intelligences like linguistic, logicalmathematical, musical, bodily-kinesthetic, spatial-visual, interpersonal, intrapersonal (Gardner 1993), different learning styles and should develop cognitive competences gaining different stages or depths of knowledge according to Norman WEBB (Albuquerque public schools 2009) starting with recalling on Level One, proceeding on the developing of different skills and concepts on Level Two and strategic thinking on Level Three. The process of transfer and extended thinking on Level Four will very often remain a vision especially in primary school. Therefore developing tasks does not only mean creating more difficult exercises, it means designing them to become more complex. Individualization via differentiation also takes place through free-work, the work with station plans, role-plays and project work. It is based on self-conducted and self-organised and very often cooperative work and develops an autonomous, socialcompetent learner, which has been the vision of any education since the "Age of Progressive Education" at the beginning of the $20^{\text {th }}$ century. Concepts like the Dalton plan of Helen Parkhurst (1886-1973 - Eichelberger 1997: 146) were based on the work with individual assignments to reach the goal of the autonomous learner. The role of the teacher changes into a supporter and a coach in special subjectbased spaces (Ebenberger 2015: 9). As the author of learning material it is his/her responsibility to create different motivating learning tasks according to the already mentioned principles.

3. Developing language competences - didactical approaches Since the start of ELT many didactical approaches have developed. Some are strictly focusing on form, like Presentation $\rightarrow$ Practice $\rightarrow$ Production (PPP), some are more meaningbased (Willis and Willis 2015: 4) like "Content and Language Integrated Learning" (CLIL) and "Task Based Teaching and Learning" (TBL), which also focuses on communication. "Total Physical Response" (TPR) concentrates on listening, there is no need of language production, "Action and Game Based Learning" uses language as a means of interaction and as part of the game. 
3.1. Content and language integrated learning

Nowadays more than $80 \%$ of the member states of the European Union provide any form of CLIL approach in their mainstream language education (Eurydice 2006: 14) in primary education as well as in secondary education. The idea of CLIL interweaves English into subject lessons or interweaves subjects and content into English lessons depending on whether teachers act as language or subject teachers.

CLIL is a dual-focused educational approach in which an additional language is used for the learning and teaching of both content AND language. That, in the teaching and learning process, there is a focus not only on content, and not only on language. Each is interwoven, even if the emphasis is greater on one or the other at a given time (Coyle et al. 2010: 1).

Coyle (2010) points out a lot of benefits for both learners and teachers: CLIL learners seem to be motivated because they are both interested in the language and in the subject. As a consequence they form more connections in their brains and develop cognitively. It has become obvious that CLIL learners are able to understand a wide range of foreign language both written and spoken, as well as in specific topics. Language competences also develop through the use of the target language in different situations. When CLIL teachers encourage learners to write and speak, pupils will become more proficient users and they will also be well prepared for studying in another language which becomes more and more crucial nowadays. One special benefit is the development of cultural awareness. "Materials in the target language may contain cultural information or attitudes which are new to the learners and teachers" (Dale and Tanner 2012: 13).

\subsection{Task based teaching and learning}

TBL can be defined in a wide spreading perspective as "a piece of work undertaken for oneself or for others ... By 'task' is meant the hundred and one things people in everyday life, at work, at play and in between" (Long 1985: 89), or with the main focus on the outcome "any structured language learning endeavour which has a particular objective, appropriate content, a specified working procedure and a 
Developing Individual Language Competences via TBL and CLIL 181

range of outcomes. 'Task' is therefore assumed to refer to a range of work-plans which have the overall purpose of facilitating language learning - from the simple and brief exercises type, to more complex and lengthy activities such as group problem-solving or simulations and decision-making" (Breen 1987:23). In brief it can be considered to be "a classroom undertaking ... where the target language is used by the learner for a communicative purpose in order to achieve an outcome" (Willis and Willis 2001: 173). Selected contents for taskbased-learning and teaching are need-based and conducted by the use of authentic material which combines classroom language, the language use outside the classroom and the learner's own professional experience. The learning process takes place via interaction in the target language and offers the chance to reflect the process itself. A good task therefore has to engage the learner's interest and has to relate to real world activities. The priority is placed on meaning and communication. There is a goal or an obvious outcome (Willis/Willis 2015). TBL requires a special procedure to gain best outcomes. Pretask-activities give an introduction to the topic, to the working process and the material that is provided and the methods that are required. The core-task/target-task has to be fulfilled in a task cycle. It consists of the task, the planning stage (of both pupils and teacher) and the outcome, which is reported (by the pupils). The post-task stage consists of follow-up exercises and of evaluation and feedback (by both pupils and teacher), which is the most important element. It has its main-focus on the development of language awareness (Brewster and Ellis 2002: 49). 


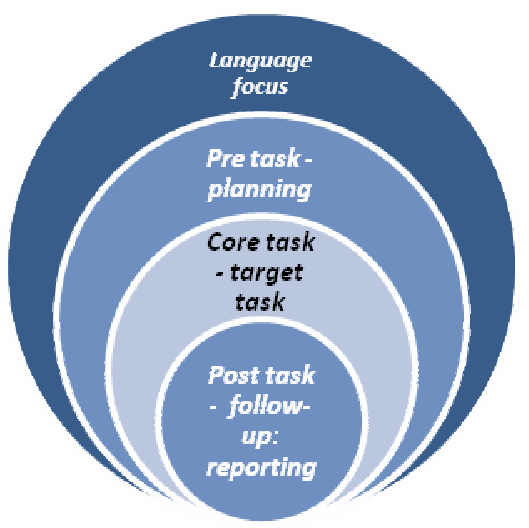

Figure 1.Procedure of TBL

There are different types of tasks (Willis and Willis 2015: 108) that can be adapted according to the different depths of knowledge or they can be placed into the scheme of multiple intelligences (Nunan 2013).

Table 2. Task types according to multiple intelligences (Nunan 2013: 59)

\begin{tabular}{|l|l|l|l|l|}
\hline $\begin{array}{c}\text { Cognitive/ } \\
\text { logical- } \\
\text { mathematical }\end{array}$ & \multicolumn{1}{|c|}{$\begin{array}{c}\text { Interper- } \\
\text { sonal }\end{array}$} & \multicolumn{1}{|c|}{ Linguistic } & $\begin{array}{c}\text { Affective/ } \\
\text { intrapersonal }\end{array}$ & Creative \\
\hline classifying & $\begin{array}{l}\text { co- } \\
\text { operating }\end{array}$ & $\begin{array}{l}\text { conversational } \\
\text { patterns }\end{array}$ & personalizing & brainstorming \\
\hline predicting & role-playing & practising & $\begin{array}{l}\text { self- } \\
\text { evaluating }\end{array}$ & \\
\hline inducing & & using context & reflecting & \\
\hline taking notes & & summarizing & & \\
\hline $\begin{array}{l}\text { concept } \\
\text { mapping }\end{array}$ & & $\begin{array}{l}\text { selective } \\
\text { listening }\end{array}$ & & \\
\hline inferencing & & skimming & & \\
\hline discriminating & & & & \\
\hline diagramming & & & & \\
\hline
\end{tabular}


Developing Individual Language Competences via TBL and CLIL 183

Figure 2.Task types according to the depth of knowledge

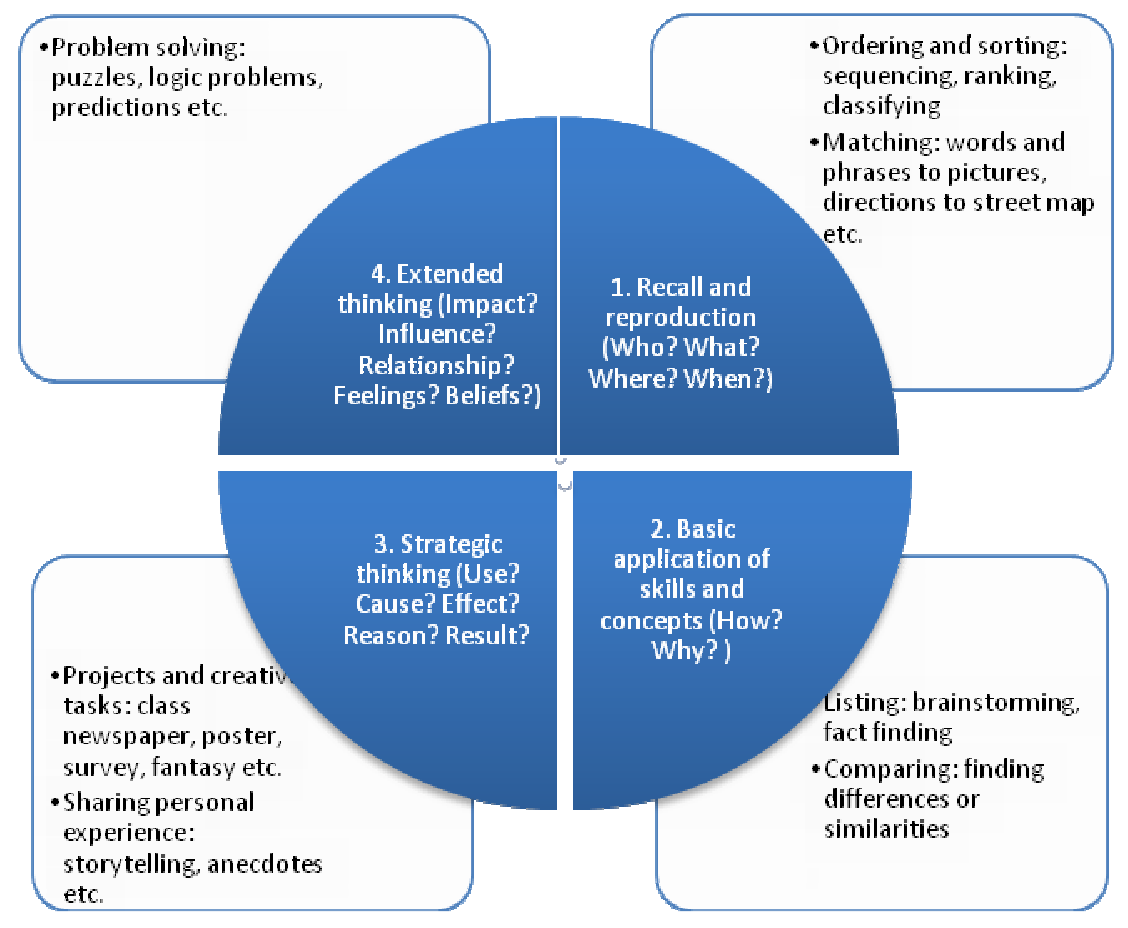

3.3. Selected examples in CLIL and TBL

The following examples were created by students of Primary Teacher Education at the University College of Teacher Education in Krems, Austria. They had to design them as outcomes in an English workshop that focused on the work in heterogeneous classes and groups. As a main goal the plans had to provide lots of possibilities to differentiate and individualize due to different skills and interests. They had to implement either CLIL or TBL-aspects as didactical approach. In their practical training lessons in different primary schools students tried out the plans. As the next step they got feedback by their teachertrainers with the special focus on differentiation and individualization. 
3.3.1. A station plan for CLIL (primary school) - A day out in spring The station plan is based on the topic "spring" and covers different subjects like maths, music, crafts, and biology. It was used in a $4^{\text {th }}$ form of primary school, when children were able to write $(9 \mathrm{y}$.), too. Some exercises are focussing on reading. Communicative skills are needed to communicate during pair or group work. According to individual approaches of learners the station plan provides tasks which address different intelligences and different stages in the depth of knowledge. The child has the choice to deal with the exercises it feels comfortable with or it is interested in. It can also set its preference on teamwork or on single work.

Table 3. CLIL- station plan

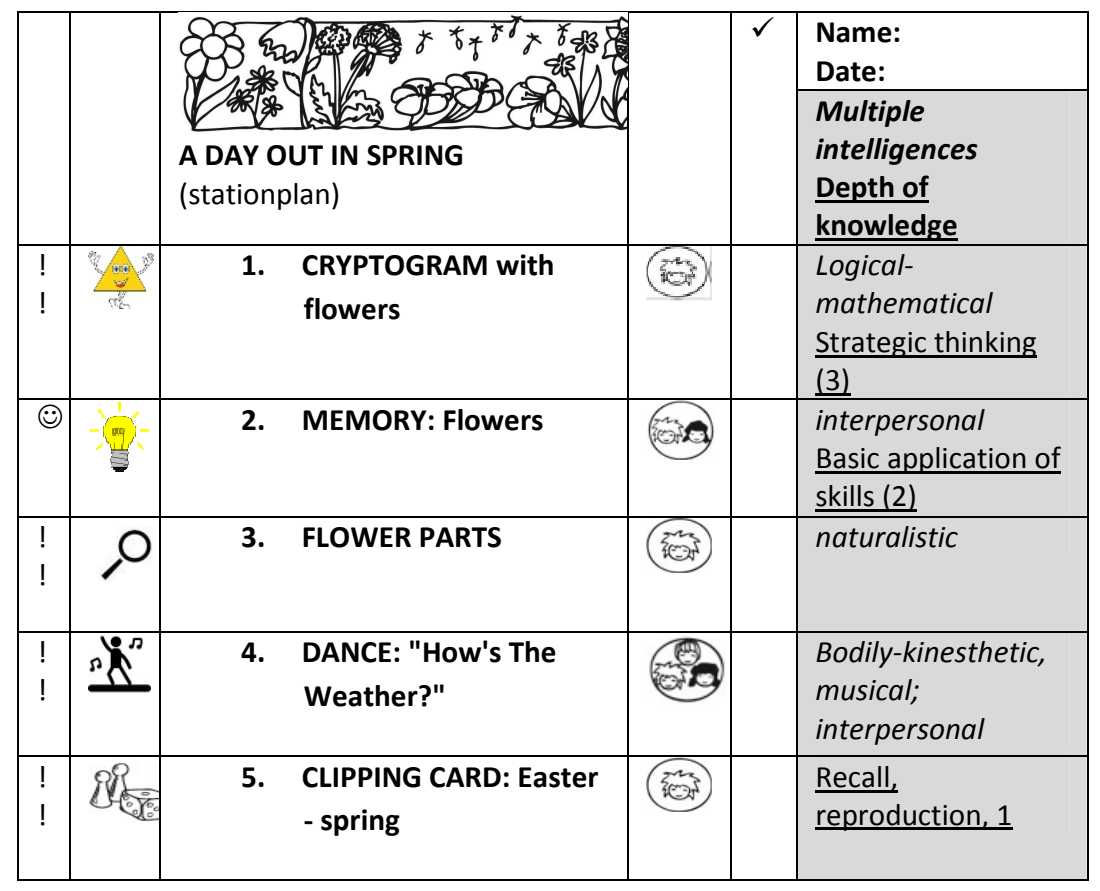


Developing Individual Language Competences via TBL and CLIL 185

\begin{tabular}{|c|c|c|c|c|c|}
\hline ;) & \& & \multicolumn{2}{|c|}{$\begin{array}{l}\text { 6. HANDICRAFT WORK: } \\
\text { Create a bird }\end{array}$} & अa & Spatial-visual \\
\hline (;) & \& & \multicolumn{2}{|c|}{ 7. BOARD GAME: spring } & (2) & interpersonal \\
\hline ! & & \multicolumn{2}{|c|}{ 8. PLANT PEPPERGRASS } & 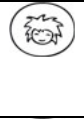 & $\begin{array}{l}\text { naturalistic } \\
\text { Strategic thinking } \\
\text { (3) }\end{array}$ \\
\hline ! & 8 & \multicolumn{2}{|c|}{ 9. THE FROG EATS... } & (mas & $\begin{array}{l}\text { linguistic } \\
\text { Recall, } \\
\text { reproduction, } 1 \\
\end{array}$ \\
\hline ! & & \multicolumn{2}{|c|}{$\begin{array}{l}\text { 10. THE LIFECYCLE OF A } \\
\text { FROG }\end{array}$} & 3 & $\begin{array}{l}\text { linguistic } \\
\text { Basic application of } \\
\underline{\text { skills (2) }}\end{array}$ \\
\hline ! & 8 & \multicolumn{2}{|c|}{ 11. ABOUT BIRDS } & ( & $\begin{array}{l}\text { linguistic } \\
\text { Recall, } \\
\text { reproduction, } 1\end{array}$ \\
\hline (;) & 呵 & \multicolumn{2}{|c|}{$\begin{array}{l}\text { 12. LETTER SOUP: } 12 \\
\text { hidden spring words }\end{array}$} & (mes & $\begin{array}{l}\text { Linguistic } \\
\text { Basic application of } \\
\text { skills (2) }\end{array}$ \\
\hline$!$ & & \multicolumn{2}{|c|}{$\begin{array}{l}\text { 13. SOUNDS of SPRING: } \\
\text { animals }\end{array}$} & (m) & naturalistic \\
\hline \multicolumn{3}{|c|}{ 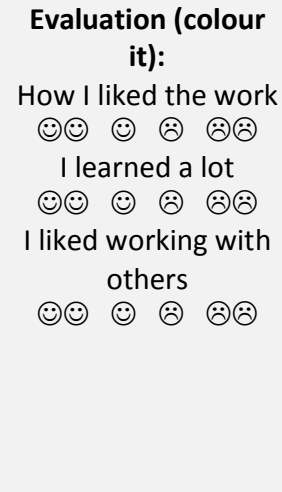 } & $\begin{array}{c}\text { Rules: } \\
\text { !! You HAVE to do it } \\
\text {;) You CAN do it } \\
\text { - Work silently } \\
\text { - Leave the place } \\
\text { proper } \\
\text { - Maximum of four } \\
\text { children at one } \\
\text { station } \\
\text { - Tick what you have } \\
\text { done } \\
\text { - Check exercises } \\
(\checkmark)\end{array}$ & \multicolumn{2}{|c|}{ Feedback of teacher: } \\
\hline
\end{tabular}


3.3.2. A task-cycle for TBL /primary school) - Hobbies - Jonathan London, Froggy rides a bike

The main idea for the students' work was to introduce a common storybook and to connect it with issues of the personal environment of the children in reference to the core curriculum. It was the students' decision whether the main focus was on the book or on the personal issue. According to the procedure of TBL it contains all stages and has to provide as many different aspects of individualization as possible. The lesson plan was put into practice in a $4^{\text {th }}$ form of primary school.

Table 4.TBL-lesson plan

\begin{tabular}{|c|c|c|c|}
\hline $\begin{array}{l}\text { Proce } \\
\text {-dure }\end{array}$ & $\begin{array}{l}\text { Competences } \\
\text { (GK4) }\end{array}$ & $\begin{array}{l}\text { Content / methodology/ } \\
\text { task type }\end{array}$ & $\begin{array}{c}\text { Multiple } \\
\text { intelligences } \\
\text { Depth of } \\
\text { knowledge }\end{array}$ \\
\hline $\begin{array}{l}\text { Pre- } \\
\text { task }\end{array}$ & $\begin{array}{l}\text { Intercultural, } \\
\text { social, personal } \\
\text { competences } \\
\text { Listening/under } \\
\text { standing } \\
\text { Join in } \\
\text { communication } \\
(1 b, 2 a)\end{array}$ & $\begin{array}{l}\text { Teacher }(T) \text { shows flashcards in } \\
\text { plenum: frog, bed, dream, bike, flip- } \\
\text { flops } \\
\rightarrow \text { speculation (dialogue with } \\
\mathrm{P}=\text { pupils) : What will the story be } \\
\text { about? } \\
T \text { explains work plan: Storytelling } \\
\rightarrow \text { core topic: hobbies } \\
T \text { tells the story, supported by } \\
\text { pictures; explains unknown words } \\
\text { Discussion in groups: Did you like } \\
\text { the story? Why? Why not? } \rightarrow \text { oral } \\
\text { group report }\end{array}$ & $\begin{array}{l}\text { linguistic, } \\
\text { basic } \\
\frac{\text { application of }}{\underline{\text { skills }}} \\
\frac{\text { recall, }}{\text { reproduction }} \\
\text { linguistic }\end{array}$ \\
\hline $\begin{array}{l}\text { Task } \\
\text { cycle }\end{array}$ & $\begin{array}{l}\text { Listening/under } \\
\text { standing } \\
\text { Join in } \\
\text { communication } \\
\text { Speaking } \\
\text { coherently } \\
\text { writing } \\
\text { Intercultural, }\end{array}$ & $\begin{array}{l}\quad \text { T explains work plan : } \\
\quad \text { collecting hobbies, } \\
\rightarrow \text { group dialogues } \\
\text { Collecting useful phrases (notes on } \\
\text { board) } \\
\text { What's your hobby? My hobby is.... } \\
\text { What do you like to do? I like... I }\end{array}$ & $\begin{array}{l}\frac{\text { basic }}{\text { application of }} \\
\frac{\text { skills }}{\text { linguistic, }}\end{array}$ \\
\hline
\end{tabular}


Developing Individual Language Competences via TBL and CLIL 187

\begin{tabular}{|c|c|c|c|}
\hline & $\begin{array}{l}\text { social, personal } \\
\text { competences } \\
\text { Writing }\end{array}$ & $\begin{array}{l}\text { don't like.... } \\
\rightarrow \text { making a group chart } \\
\rightarrow \text { create a poster } \\
\rightarrow \text { present it } \\
\rightarrow \text { give feedback according to } \\
\text { question points } \\
\text { Collecting the question points (notes } \\
\text { on the board) } \\
\rightarrow \text { Was the oral presentation clear? } \\
\text { Good English? Fluent? } \\
\rightarrow \text { How was the poster? Colourful? A } \\
\text { mess? Creative? Clear? } \\
\qquad \quad \text { Ps start with flashcard } \\
\text { activities in plenum } \rightarrow \text { matching, } \\
\text { miming, describing ...... } \\
\text { Ps make (guided) pair-interviews get } \\
\text { a personal chart and fill it in (move } \\
\text { around in class, find Ps with the } \\
\text { same symbols in the charts and ask } \\
\text { them) } \\
\bullet \quad \text { Ps form groups (same } \\
\text { symbols on the personal charts) } \rightarrow \\
\text { make a survey } \rightarrow \text { fill it in } \\
\rightarrow \text { decorate the poster with items of } \\
\text { the story book } \\
\bullet \quad \text { Ps train group } \\
\rightarrow \text { Group presentations } \\
\bullet \quad \text { Ps / } T \text { give feedback on the } \\
\quad \text { outcome }\end{array}$ & $\begin{array}{l}\frac{\text { basic }}{\text { application of }} \\
\frac{\text { skills }}{\underline{\text { strategic }}} \\
\frac{\text { thinking }}{\text { recall, }} \\
\frac{\text { reproduction }}{\text { spatial-visual }} \\
\text { logic- } \\
\text { mathematical } \\
\text { interpersonal } \\
\text { extended } \\
\text { thinking }\end{array}$ \\
\hline $\begin{array}{l}\text { Post- } \\
\text { task }\end{array}$ & $\begin{array}{l}\text { Speaking } \\
\text { coherently 1a, } \\
1 b, 1 c \\
\text { Join } \\
\text { communication } \\
(1 b, 2 a) \\
\text { Listening/under } \\
\text { standing } \\
\text { Writing }\end{array}$ & $\begin{array}{l}\text { Ps talk about the whole } \\
\quad \text { process } \\
\quad \text { Ps choose follow-up tasks: } \\
\rightarrow \text { Find another story ending } \rightarrow \text { tell it } \\
\text { to the T } \\
\rightarrow \text { Write about your hobby, use the } \\
\text { phrases on the board } \\
\rightarrow \text { Draw a picture of your hobbies } \\
\rightarrow \text { fix some important words } \\
\rightarrow \text { Draw a picture of your hobbies }\end{array}$ & $\begin{array}{l}\frac{\text { extended }}{\text { thinking }} \\
\text { linguistic; basic } \\
\text { application } \\
\text { spatial-visual } \\
\text { bodily- } \\
\text { kinesthetic; } \\
\text { recall } \\
\text { linguistic, } \\
\text { bodily- }\end{array}$ \\
\hline
\end{tabular}




\begin{tabular}{|c|c|c|c|}
\hline & & $\begin{array}{l}\rightarrow \text { Consider miming } 2 \text { hobbies } \\
\qquad \quad \text { Game - plenum: Miming: } \\
\text { can you guess the hobby? } \\
\text { Whose is it? } \rightarrow \text { questions, } \\
\text { answers }\end{array}$ & kinesthetic \\
\hline
\end{tabular}

\section{Conclusion}

CLIL and TBL can be considered to be appropriate didactical approaches to support differentiation and individualization. The examples above were realized in classes and got their feedback - as around 15 others which were created by students - by the teachertrainers. As a result nearly all of the plans were considered motivating and in their realisation children appreciated the chance of working individually and autonomously. To get results concerning the individual development of skills, further research has to be conducted comparing a normal and a focus group that is mainly taught via CLIL or TBL. In any way it is crucial that pupils are familiar with strategies and methods. They need a lot of practice to deal with the given instructions (Legutke et al. 2015: 42). Using different methods should be part of any teaching. Methodological competences need training to become efficient and to lead to self-conducted learning. As a matter of fact, CLIL and TBL need a lot of preparation work by the teachers sthat is considered very time-consuming as it is hardly ever found in the course-books. In Austrian course-books you will find chapters that provide CLIL. TBL teachers have to be very selective and critical when they use course-books. There are very often disguised tasks which demand role-play, discussion etc., but most of the so-called 'tasks' in course-books are form-based.

Some teachers also doubt whether the two approaches are suitable for young learners, they fear losing control when pupils work autonomously and they complain about a lack of progress in the development of skills (Willis/Willis 2015:200). The argument of pressure because of the necessity of grading becomes obsolete in primary schools in Austria. Teachers must take this chance and therefore plan and realize lessons that support the individual 
Developing Individual Language Competences via TBL and CLIL 189

development of pupils. Personal didactical decisions must be based on reflection, experience and research and may not depend on the suggestions of course-books. They will become straight-jackets, and methodological development will get stuck.

References

Albuquerque public schools (2009). Webb's Depths of Knowledge Guide. Online: http://www.aps.edu/re/documents/resources/Webbs_DOK_Guide.pdf (date of access: July 17, 2016).

Altrichter, H. \& Hauser, B. (2007). Umgang mit Heterogenität lernen. Journal für Lehrerinnen- und Lehrerbildung, 1/2007, 4-11.

BGB1. II Nr. 303/2012. Lehrplan der Volksschule, 246. Online. https://www.bmbf.gv.at/schulen/unterricht/lp/lp_vs_gesamt_14055.pdf?4d zgm2 (date of access: July 2, 2015).

BGBL II, Nr. 1/2009. Bildungsstandards im Schulwesen. Online. https://www.ris.bka.gv.at/GeltendeFassung.wxe?Abfrage=Bundesnormen \&Gesetzesnummer $=20006166$ (date of access: July 17, 2016).

Bgbl. II Nr. 185/2012 / Bgbl. II Nr. 174/2015. Lehrplan der Neuen Mittelschule. Online submission: https://www.ris.bka.gv.at/GeltendeFassung.wxe?Abfrage=Bundesnormen $\&$ Gesetzesnummer=20007850. (date of access: July 17the, 2016).

Breen, M. (1987). Learner contributions to task design. In Candlin, C., Murphy, D (eds.), Language Learning Tasks (pp. 23-46). Englewood Cliffs NJ: Prentice Hall.

Brewster, J. \& Ellis, G. (2002). The Primary English Teacher's Guide. New Edition. Harlow: Pearson Education.

Council of Europe (2001). Common European Framework of Reference for Languages.

Online: http://www.coe.int/t/dg4/linguistic/source/framework_en.pdf (date of access: July 18, 2016).

Coyle, D., Hood, P., \& Marsh, D. (2010). CLIL. Cambridge: Cambridge University Press.

Dale, L., \& Tanner, R. (2012). CLIL Activities. A Resource for Subject and Language Teachers. Cambridge: Cambridge University Press. 
Ebenberger, A. (2015). Development of the Austrian educational system From a new teaching philosophy to a new educational system. In: Silva, E., Pais, C., Pais, L. P. (eds.), $10^{\text {th }} I P B$ Erasmus Week, Teaching Crossroads (pp. 13-14). Braganca: Instituto Politecnico de Braganca.

Eichelberger, H. (1997). Freiheit für die Schule. Wien: Holzhausen.

Eurydice (2006). Content and Language Integrated Learning (CLIL) at School in Europe. Online. http://www.indire.it/lucabas/lkmw_file/eurydice/CLIL_EN.pdf (date of access: April 19, 2016)

Gardner, H. (1993). Frames of Mind. The Theory of Multiple Intelligences. New York: Basic Books

Legutke, M.1, Müller-Hartmann, A., Schocker v. Ditfurth, M. (2015). Teaching English in the Primary School. Stuttgart: Klett.

Long, M. (1985). A role for instruction in second language acquisition. In Hyltenstam, K., Pienemann, M. (eds.), Modelling and Assessing Second Language Acquisition (pp. 77-99). Clevedon, Avon: Multilingual Matters.

Österreichisches Sprachenkompetenzzentrum (ÖSZ). (2015). Grundkompetenzen Lebende Fremdsprache 2. und 4. Schulstufe (Gk2/Gk4). Online: http://www.oesz.at/download/Attachments/gk2gk4_infofolder_2015_web. pdf (date of access: July 17, 2016).

Nunan, D. (2013). Task-Based Language Teaching. Cambridge: Cambridge University Press

Salner-Gridling, I. (2009). Querfeldein: individuell lernen - differenziert lehren. Wien: ÖZEPS.

Willis, D., \& Willis, J. (2001). Task-based language learning. In Carter, R., Nunan, D. (eds), The Cambridge Guide to Teaching English to Speakers of Other Languages (pp. 173-179). Cambridge: Cambridge University Press.

Willis, D., \& Willis, J. (2015). Doing Task-Based-Teaching. Oxford: Oxford University Press. 